\title{
CRIME DE DESACATO, DEMOCRACIA E LIBERDADE DE EXPRESSÃO NA AMÉRICA LATINA
}

\author{
CRIME OF CONTEMPT, DEMOCRACY AND FREEDOM OF EXPRESSION IN \\ LATIN AMERICA
}

\author{
Marcos Alves da Silva ${ }^{1}$ \\ Violeta Sarti Caldeira ${ }^{2}$ \\ Marine Morbini Durante ${ }^{3}$
}

\section{RESUMO}

O presente artigo visa demonstrar a análise histórica que ensejou a criação do tipo penal do desacato, bem como a análise de julgados recentes que demonstram como esse crime acaba por realizar a autocensura, restringindo a liberdade de expressão e afetando diretamente a democracia.

Palavras-chave: Democracia. Desacato. Brasil. América Latina. Arbitrariedade.

\section{ABSTRACT}

This article aims to demonstrate the historical analysis that led to the creation of the criminal type of contempt, as well as the analysis of recent judgments that demonstrate how this crime ends up performing self - censorship, restricting freedom of expression and directly affecting democracy.

\footnotetext{
${ }^{1}$ Doutor em Direito Civil pela Universidade do Estado do Rio de Janeiro - UERJ (2012). Mestre em Direito pela Universidade Federal do Paraná - UFPR (2001). Graduado em Direito pela Universidade Federal do Paraná (1995). Advogado. Professor da Escola da Magistratura do Paraná - EMAP. Professor da Fundação Ministério Público do Estado do Paraná - FEMPAR. Professor Permanente do Programa de Mestrado em Direito Empresarial e Cidadania do UNICURITIBA. Realiza estágio PósDoutoral na Universidade Nova de Lisboa (2016/2017).

2 Graduada em Ciências Sociais pela Pontifícia Universidade Católica de São Paulo (PUC/SP), em 2006. Mestra em Ciências Sociais também pela PUC/SP, em 2009 e Doutora em Sociologia Política pela Universidade Federal do Paraná, em 2017. Atualmente ministra aulas de Ciência Política, Sociologia e Antropologia nos cursos de Direito (desde 2009) e Relações Internacionais (desde 2015) do Centro Universitário Curitiba e Antropologia e Sociologia no Curso de Direito da Universidade Positivo (desde 2017). Atua principalmente nos seguintes temas: direitos difusos e coletivos, ação civil pública, Poder Judiciário, Ministério Público e representação política.

3 Graduada em Direito pelo Centro Universitário Curitiba em 2019. Pós-graduanda em Direito Constitucional pela ABDCONST. Pós-graduanda em Direito Penal Econômico pela Escola da Magistratura Federal do Paraná-ESMAFE.
} 
Keywords: Democracy. Contempt. Brasil. Latin America. Arbitrariness.

\section{INTRODUÇÃO}

O presente artigo científico busca analisar o histórico e jurisprudência mais recente a respeito do crime de desacato, em nível nacional e internacional, compreendendo ainda as duas últimas paradigmáticas decisões do STJ. A primeira, ocorrida em dezembro de 2016, afirmando que deve ocorrer a abolitio criminis, e a segunda, que aponta que o crime deve permanecer na legislação, publicada no início de 2017.

A justificativa se dá, portanto, pela relevância e atualidade do tema.

Além da análise jurisprudencial, examina-se também o contexto político no qual o crime foi inserido no Brasil, procurando compreender o caráter autoritário deste. Ainda, pretende-se demonstrar a arbitrariedade com que vem sendo aplicado pelo judiciário, fazendo-se necessário que a Corte Interamericana de Direitos Humanos, bem como a Comissão Interamericana de Direitos Humanos, viessem a se pronunciar sobre o tema.

No artigo "O crime de desacato e a sua correlação com a atitude repressiva estatal", Laura Garbini BOTHANE e Elise Brandalise GONÇALVES afirmam que:

Infelizmente, por mais que a legislação penal tenha sido usada como auxílio da Ditadura Militar, ainda com o advento de um novo sistema constitucional brasileiro, democrático e aberto, crimes como o desacato permanecem no Código Penal, sob os mesmos argumentos (da honra funcional, do prestígio da Administração Pública, da autoridade estatal, etc.). ${ }^{3}$

Os órgãos do Sistema Interamericano de Proteção dos Direitos Humanos, composto pela Corte Interamericana de Direitos Humanos (Corte IDH) e pela Comissão Interamericana de Direitos Humanos (Comissão IDH) já possuem jurisprudência e diversos relatórios contrários à penalização da conduta, porque ele

\footnotetext{
3 BOTHANE, Laura Garbini; GONÇALVES, Elise Brandalise. O crime de desacato e sua correlação com a atitude repressiva estatal. Revista Quaestio luris, Rio de Janeiro, n. 1, v. 10, Setembro 2016. p.554.
} 
fere um dos pilares do Estado Democrático de Direito: a liberdade de expressão. Assim, afirmam ainda que as leis de desacato acabam por proteger os governos das críticas, sendo que em uma sociedade democrática, personalidades públicas e políticas devem estar mais expostas às críticas e ao debate amplo e aberto, e não menos, como pretende o crime de desacato, limitando a liberdade de expressão.

A Comissão IDH mantém uma bienal tradição de analisar a situação das leis de desacato nos países da América Latina através do Informe Anual de la Relatoria para laLibertad de Expressión, sempre tendo resultados positivos, visto que o número de países que ainda preservam o crime está decaindo progressivamente.

Ainda de acordo com o artigo citado anteriormente, é curioso observar o modo com que o crime de desacato vem sendo abolido nos outros países da América Latina comparado com a tendência do Brasil. É que em outros países como Chile, Argentina, Costa Rica, Paraguai, o crime de desacato acaba sendo abolido depois de alguma personalidade notória ter seu direito de liberdade de expressão ferido por conta do crime de desacato, momento em que, casuisticamente, o crime acaba sendo extirpado do ordenamento jurídico pelos tribunais pátrios ou então pela Corte Interamericana de Direitos Humanos, dependendo do caso.

No Brasil, vamos no caminho inverso. O que se observa é que em vez de termos um único caso emblemático envolvendo uma personalidade notória, temos uma excessiva quantidade numérica, ou seja, um número excessivo de $\operatorname{casos}^{4}$, o que indica que a aplicação do crime está sendo exagerada e arbitrária.

\section{HISTÓRICO DO CRIME DE DESACATO}

O crime de desacato, previsto no artigo 331 do Código Penal Brasileiro, segundo Fernando CAPEZ, consiste em:

Desacatar (qualquer ato ou emprego de palavras que causem vexame, humilhação ao funcionário público). Engloba-se o emprego de violência (lesões corporais ou vias de fato), utilização de gestos ofensivos, no uso de

${ }^{4} \mathrm{O}$ artigo fala em 1.896 ocorrências policiais de desacato registradas pela Polícia Militar de Minas Gerais, em todo o Estado, no trimestre de abril a maio de 2009. 
expressões caluniosas, difamantes ou injuriosas, enfim, todo ato que desprestigie, humilhe o funcionário, de forma a ofender a dignidade, o prestígio e o decoro da função pública. É preciso que o desacato seja praticado contra funcionário público no exercício de sua função (in officio). ${ }^{5}$

Como o crime está inserido no Título XI, "Dos crimes contra a administração pública”, Capítulo II, “Dos crimes praticados por particular contra a administração em geral", significa que o bem jurídico tutelado por ele, ou seja, o que se pretende proteger é a administração pública, afinal se fosse a honra do funcionário público, o crime estaria inserido no Capítulo V do Título I do Código Penal, "Dos crimes contra a honra". É nesse sentido que vem César Roberto BITENCOURT:

Bem jurídico protegido é a Administração Pública, especialmente sua moralidade e probidade administrativa. Protege-se, na verdade, a probidade de função pública, sua respeitabilidade, bem como a integridade de seus funcionários. Objetiva-se, especificamente, garantir o prestígio e a dignidade da "máquina pública" relativamente ao cumprimento de determinações legais, expedidas por seus agentes. É considerado crime pluri ofensivo, atingindo tanto a honra do funcionário como o prestígio da Administração Pública. ${ }^{6}$

No Direito Romano não existia o crime autônomo de desacato, mas sim uma injuria agravada, e o sujeito passivo do crime eram somente os juízes, durante o ofício e depois dele, desde que em razão de sua função.

Segundo Álvaro Mayrink da COSTA:

A injúria agravada era punida severamente com a pena de deportatio in insulam para os honestiores e com a pena de morte para os humiliores. No antigo Direito romano, a injúria era sempre agravada quando consumado o dano ao magistrado no exercício de suas funções (...). A teoria romana da injúria agravada foi ampliada na prática, sendo considerada durante officio e também post officium, desde que fosse contemplatione offici. ${ }^{7}$

$\mathrm{Na}$ idade média, houve uma ampliação da aplicabilidade da injúria agravada, como se percebe na obra do mesmo autor, onde os sacerdotes foram incluídos como

\footnotetext{
${ }^{5}$ CAPEZ, Fernando; Prado, Stela. Código penal comentado. Saraiva, 2016. $7^{\circ}$ Edição. p. 672.

${ }^{6}$ BITENCOURT, César Roberto. Código penal comentado. Saraiva, 2015. 9 Edição. p. 1447.

7 COSTA, Álvaro Mayrink Da. Direito penal: Parte especial injustos contra a administração pública. Volume 7. Cidade: Forense, 2011. 6ํㅡㄹição. p. 219, 220
} 
sujeitos passivos do delito, e também este podia ser cometido no exercício de sua função, ou em razão desta, sendo dessa forma mais abrangente:

\begin{abstract}
Recebeu, por obra dos práticos, a doutrina romana, considerando a ofensa ao funcionário público como ofensa ao decoro e à autoridade do Estado, e, por consequência, ao príncipe que o personificava (...) A prática intermédia ampliou a esfera de violação em dois sentidos: a) a proteção reforçada que se estendia a outras categorias de pessoas (sacerdotes); e b) a punição aos funcionários in officium e também propter officium. ${ }^{8}$
\end{abstract}

De acordo com Cesar Roberto BITTENCOURT ${ }^{9}$, posteriormente, na França, é que o desacato se tornou um crime autônomo, com as codificações em 1820, tendo a sua aplicação estendida também para outros funcionários públicos, justificando a criminalização na necessidade dos agentes públicos em exercer de modo eficaz a sua função.

No Brasil, o crime de desacato era embrionário nas Ordenações Filipinas, constatado no Livro V, Título L, "Dos que fazem ou dizem injúrias aos Julgadores, ou a seus Officiais", visto que se punia os que injuriassem os desembargadores, corregedores, ouvidores, juízes ou outro qualquer julgador, mas não havia o tipo penal autônomo de desacato como há hoje.

O código criminal de 1830 também não tinha o desacato como tipo autônomo, visto que estabelecia no seu art. 231 :

Art. 231. Se a calúnia fôr contra qualquer Depositário, ou Agente de Autoridade publica, em razão do seu ofício.

Penas - de prisão por seis a dezoito meses, e de multa correspondente á metade do tempo. ${ }^{10}$

Foi o Código penal de 1890 que tornou a conduta de injuriar funcionário público como o tipo penal autônomo de desacato, onde previa que a pena deveria ser

\footnotetext{
8lbidem. p. 220

${ }^{9}$ BITTENCOURT, Op. Cit. p. 216

${ }_{10}$ BRASIL. Código Criminal do Império do Brasil. Disponível em: <http://www.planalto.gov.br/ccivil_03/leis/lim/LIM-16-12-1830.htm> Acesso em: set 2017
} 
aumentada de um terço se o desacato ocorresse em qualquer repartição pública, a ver:

Art. 134. Desacatar qualquer autoridade, ou funccionario publico, em exercicio de suas funcções, offendendo-odirectamente por palavras ou actos, ou faltando á consideração devida e á obediência hierarchica:

Pena - de prisão cellular por dous a quatro mezes, além das mais em que incorrer.

Paragraphounico. Si o desacato for praticado em sessão publica de camaras legislativas ou administrativas, de juizes ou tribunaes, de qualquer corporação docente ou dentro de alguma repartição publica:

Pena - a mesma, com aumento da terça parte. ${ }^{11}$

Nas palavras de César Roberto Bitencourt:

O Código Penal de 1890, por sua vez, recepcionou essa infração penal atribuindo-lhe o nomen juris de desacato, punindo a conduta de "desacatar qualquer autoridade, ou funcionário público, em exercício de suas funções, ofendendo-o diretamente por palavras ou atos, ou faltando à consideração devida e à obediência hierárquica" (art. 134). Considerava, no entanto, qualificado se a infração fosse praticada em sessão opública ou dentro de repartição pública. ${ }^{12}$

É com o atual Código penal de 1940 que temos a seguinte redação:

Art. 331 - Desacatar funcionário público no exercício da função ou em razão dela:

Pena - detenção, de seis meses a dois anos, ou multa. ${ }^{13}$

Segundo Cesar Roberto BITTENCOURT ${ }^{14}$, foi com esse código penal que tivemos a ampliação da aplicabilidade do crime, se assemelhando ao disposto no antigo Direito Romano, que punia os atos que ocorressem no exercício da função do servidor público ou em razão dela: "Finalmente, o atual Código Penal de 1940 ampliou

\footnotetext{
11 BRASIL. Código Penal de 1890. Disponível em: <http://www2.camara.leg.br/legin/fed/decret/18241899/decreto-847-11-outubro-1890-503086-publicacaooriginal-1-pe.html> Acesso em: set 2017.

12 BITENCOURT, Op. Cit.p. 216, 217

13 BRASIL. Código Penal de 1890. Disponível em: <http://www2.camara.leg.br/legin/fed/decret/1824 1899/decreto-847-11-outubro-1890-503086-publicacaooriginal-1-pe.html>. Acesso em: set 2017.
} 
o alcance da tipificação penal para abranger as ofensas proferidas contra funcionário público no exercício da função como também em razão dela".

Dessa forma, o dispositivo também estendeu a aplicação do delito a qualquer tipo de funcionário público, onde antes era restrito a membros do poder judiciário.

Segundo o artigo "O crime de desacato e sua correlação com a atitude repressiva estatal”, de Laura Garbini Botho e Elise Brandalise Gonçalves:

Contudo, se da leitura de toda legislação penal brasileira verifica-se que se antes o desacato era voltado à proteção do magistrado e de seus funcionários, o Código Penal de 1940 abrangeu o leque de proteção a todo funcionário público em exercício (ou em razão de seu ofício), com um tipo penal aberto, apto a possibilitar a penalização de uma série de condutas. ${ }^{15}$

Concluímos então que o crime de desacato, na sua origem, era utilizado somente para proteger a honra funcional dos juízes, tendo sua aplicabilidade alargada com o passar do tempo, chegando até os tempos atuais onde alcança todos os funcionários públicos. Como visto, foi o Código Penal de 1890 que trouxe a tipificação do crime de desacato, mas o atual Código de 1940 é que estendeu a sua aplicabilidade, visto que foi criado e aprovado na Era Vargas, período totalitário de nossa história.

\section{ANÁLISE DOS JULGADOS SOBRE O CRIME DE DESACATO NO BRASIL}

Recentemente, em dezembro de 2016, o Superior Tribunal de Justiça, no julgamento do RESP 1640084/SP, tendo como relator o Ministro Ribeiro Dantas da quinta turma, decidiu que o crime de desacato não deveria ser aplicado ao caso em tela, visto que ele é contrário ao entendimento da Corte Internacional de Direitos Humanos e aos Pactos dos quais o Brasil é signatário, a ver:

${ }^{15}$ BOTHANE, Laura Garbini; GONÇALVES, Ane Elise Brandalise. Op Cit. p.554. 
EMENTA DIREITO PENAL E PROCESSUAL PENAL. RECURSO ESPECIAL. ROUBO, DESACATO E RESISTÊNCIA. APELAÇÃO CRIMINAL. EFEITO DEVOLUTIVO AMPLO. SUPRESSÃO DE INSTÂNCIA. NÃO OCORRÊNCIA. ROUBO. PRINCÍPIO DA INSIGNIFICÂNCIA. INAPLICABILIDADE. DESCLASSIFICAÇÃO DO CRIME DE ROUBO PARA O DE CONSTRANGIMENTO ILEGAL. AUSÊNCIA DE FUNDAMENTAÇÃO. SÚMULA 284/STF. TEMA NÃO PREQUESTIONADO. SÚMULAS 282 E 356 DO STF. DESACATO. INCOMPATIBILIDADE DO TIPO PENAL COM A CONVENÇÃO AMERICANA DE DIREITOS HUMANOS. CONTROLE DE CONVENCIONALIDADE.

4. O art. $2^{\circ}$, c/c o art. 29, da Convenção Americana de Direitos Humanos (Pacto de São José da Costa Rica) prevê a adoção, pelos Estados Partes, de "medidas legislativas ou de outra natureza" visando à solução de antinomias normativas que possam suprimir ou limitar o efetivo exercício de direitos e liberdades fundamentais.

5. Na sessão de 4/2/2009, a Corte Especial do Superior Tribunal de Justiça, ao julgar, pelo rito do art. 543-C do CPC/1973, o Recurso Especial 914.253/SP, de relatoria do Ministro LUIZ FUX, adotou o entendimento firmado pelo Supremo Tribunal Federal no Recurso Extraordinário 466.343/SP, no sentido de que os tratados de direitos humanos, ratificados pelo país, têm força supralegal, "o que significa dizer que toda lei antagônica às normas emanadas de tratados internacionais sobre direitos humanos é destituída de validade."

9. Por conseguinte, a ausência de lei veiculadora de abolitio criminis não inibe a atuação do Poder Judiciário na verificação da inconformidade do art. 331 do Código Penal, que prevê a figura típica do desacato, com o art. 13 do Pacto de São José da Costa Rica, que estipula mecanismos de proteção à liberdade de pensamento e de expressão.

10. A Comissão Interamericana de Direitos Humanos - CIDH já se manifestou no sentido de que as leis de desacato se prestam ao abuso, como meio para silenciar ideias e opiniões consideradas incômodas pelo establishment, bem assim proporcionam maior nível de proteção aos agentes do Estado do que aos particulares, em contravenção aos princípios democrático e igualitário.

11. A adesão ao Pacto de São José significa a transposição, para a ordem jurídica interna, de critérios recíprocos de interpretação, sob pena de negação da universalidade dos valores insertos nos direitos fundamentais internacionalmente reconhecidos. Assim, o método hermenêutico mais adequado à concretização da liberdade de expressão reside no postulado prohomine, composto de dois princípios de proteção de direitos: a dignidade da pessoa humana e a prevalência dos direitos humanos.

12. A criminalização do desacato está na contramão do humanismo, porque ressalta a preponderância do Estado - personificado em seus agentes - sobre o indivíduo.

13. A existência de tal normativo em nosso ordenamento jurídico é anacrônica, pois traduz desigualdade entre funcionários e particulares, o que é inaceitável no Estado Democrático de Direito.

14. Punir o uso de linguagem e atitudes ofensivas contra agentes estatais é medida capaz de fazer com que as pessoas se abstenham de usufruir do direito à liberdade de expressão, por temor de sanções penais, sendo esta uma das razões pelas quais a CIDH estabeleceu a recomendação de que os países aderentes ao Pacto de São Paulo abolissem suas respectivas leis de desacato.

15. O afastamento da tipificação criminal do desacato não impede a responsabilidade ulterior, civil ou até mesmo de outra figura típica penal 
(calúnia, injúria, difamação etc.), pela ocorrência de abuso na expressão verbal ou gestual utilizada perante o funcionário público.

16. Recurso especial conhecido em parte, e nessa extensão, parcialmente provido para afastar a condenação do recorrente pelo crime de desacato (art. 331 do CP). ${ }^{16}$

O ponto chave da discussão deste RESP se baseia em que se há a tipificação de um crime na legislação pátria, que diminui a liberdade e lesa direitos humanos, quando há recomendações expressas de órgãos internacionais que resguardam esses mesmos direitos para que ele seja retirado do ordenamento jurídico, seria papel imprescindível do judiciário não aplicá-lo em casos concretos, fazendo o controle de convencionalidade entre as normas.

Além desse crime ser inconvencional (contra as convenções internacionais ratificadas pelo Brasil), é um crime também inconstitucional, porque os pilares da Constituição de 1988 são a liberdade, a dignidade da pessoa humana, o Estado Democrático de Direito, e a igualdade. Deve-se considerar também que há o Princípio da Intervenção Mínima, ou seja, de que o direito penal deve ser usado somente como ultimaratio.

Antes desta consagrada decisão do STJ, já tínhamos algumas decisões esparsas de juízes aplicando as Convenções de Direito Humanos, afastando a aplicabilidade do crime de desacato:

PODER JUDIÁRIO. Estado de Santa Catarina. Ação Penal - Procedimento Sumário/PROC no 0067370-64.2012.8.24.0023. Juiz de Direito Alexandre Moraes da Rosa. 17 mar. 2015.

A partir da exposição galgaremos decisão Exmo Juiz de Direito Alexandre Moraes da Rosa da 4a Vara Criminal do Estado de Santa Catarina no processo 0000428-43.2012.8.24.0090:

Policiais militares encontravam-se em policiamento ostensivo quando avistaram uma briga generalizada, envolvendo diversas pessoas, e que, diante da intervenção policial, a contenda foi apaziguada, acalmando-se os ânimos de todos, com exceção do denunciado A. S., que mostrava-se ainda agressivo e gritando muito. Ao the ser solicitado que se acalmasse, o denunciado, em tom de deboche, afirmou "que não gostava de polícia e que eram todos lotes de bichos, arrogantes e que não serviam para nada", negando-se a prestar qualquer esclarecimento sobre a briga, "muito menos para uma policial feminina, porque mulher era para estar em casa dormindo".

${ }^{16}$ BRASIL, Superior Tribunal de Justiça. RESP № 1.640.084 - SP (2016/0032106-0). Disponível em: $<$ http://www.stj.jus.br/static_files/STJ/Midias/arquivos/Noticias/RECURSO\%20ESPECIAL\%20N\%C2\% BA\%201640084.pdf>. Acesso em: out, 2017. 
Ao ser informado de que estava preso em razão do desacato proferido, o denunciado tentou fugir, mas mesmo detido em seguida, resistiu fortemente à prisão, com socos e empurrões, sendo necessária a atuação de quatro policiais para contê-lo. Mesmo após detido e algemado, o denunciado apresentou resistência e continuou a ofender os policiais militares, tudo na presença de diversas pessoas que acudiram ao acontecimento.

Isso posto, importa destacar, de início, que o controle de compatibilidade das leis não se trata de mera faculdade conferida ao julgador singular, mas sim de uma incumbência, considerado o princípio da supremacia da Constituição. Cabe ainda frisar que, no exercício de tal controle, deve o julgador tomar como parâmetro superior do juízo de compatibilidade vertical não só a

Constituição da República (no que diz respeito, propriamente, ao controle de constitucionalidade difuso), mas também os diversos diplomas internacionais, notadamente no campo dos Direitos Humanos, subscritos pelo Brasil, os quais, por força do que dispõe o art. $5^{\circ}$, $\S \S 2^{\circ}$ e $3^{\circ}[1]$, da Constituição da República, moldam o conceito de "bloco de constitucionalidade" (parâmetro superior para o denominado controle de convencionalidade das disposições infraconstitucionais). ${ }^{17}$

Assim, segundo o exímio juiz Alexandre Moraes da Rosa, é dever do juiz afastar a aplicabilidade de uma norma que viola a Constituição e os Tratados Internacionais, ainda mais os que tratam de direitos humanos.

O que se deve ter em mente, é que quando se sugere que o crime de desacato não deveria mais ter vigor, não se está dizendo que os servidores públicos possam ser menosprezadas e sofrer todos os tipos de ofensa das demais pessoas. O que se defende é que esse crime poderia muito bem ser abrangido pelas formas de crimes contra a honra já existentes no Código Penal, presentes no Capítulo V, sendo a Calúnia, do art. 138, a Difamação do art. 139 e a Injúria do art. 140, sem falar na composição civil dos danos efetivamente causados.

Em suma, o que se analisa é que o crime de desacato é muito aberto, recheado de possíveis interpretações, não havendo um conceito fechado para dizer se houve o crime ou não. Como por exemplo, no caso do crime de homicídio, para que este se consume, precisa-se que ocorra a morte, e o próprio Direito traz o conceito de morte, ou seja, não gera dúvidas nem várias possíveis interpretações, havendo a morte, (que para o Direito é a parada de atividade cerebral), há a consumação do homicídio.

17 EMPÓRIO DO DIREITO. Desacato não é crime, diz Juiz em controle de convencionalidade. Disponível em: <http://emporiododireito.com.br/backup/desacato-nao-e-crime-diz-juiz-em-controle-deconvencionalidade/>. Acesso em: out, 2017. 
No desacato, um mesmo dizer " $X$ " proferido para diferentes agentes estatais pode ser considerado como ofensa ou não, dependendo da emotividade deste. $\mathrm{Ou}$ seja, o Direito (lei) não é capaz de dizer quando se consumaria essa ofensa, porque para uma pessoa o dizer "X" pode ofender, enquanto que para outra pessoa, não. É subjetivo. Somente o poder judiciário quando for julgar o caso, havendo muita margem para interpretação, é que poderá dizer se o crime ocorreu ou não.

Segundo Nucci:

Se o funcionário público demonstra completo desinteresse pelo ato ofensivo proferido pelo agressor, não há que se falar em crime, mas caso o funcionário seja efetivamente humilhado, no exercício de sua função, a sua concordância é irrelevante, pois o crime é de ação pública incondicionada. ${ }^{18}$

É justamente neste ponto que reside a arbitrariedade, ponto já atentado por Cesare BECCARIA ${ }^{19}$ em 1764, quando defendia o princípio da legalidade, fazendo com que não haja tanta margem de discricionariedade para o judiciário. Pior ainda fica quando vítima do crime e o ente julgador deste fazem parte da mesma instituição: o Estado.

Infelizmente, a decisão mais recente sobre o assunto do crime de desacato no Brasil é a do STJ, de 24/05/17, do Ministro Relator Antônio Saldanha Pinheiro, de que o delito deve continuar vigente na legislação penal. ${ }^{20}$

O argumento central apresentado pelo ministro é de que as Convenções internacionais utilizadas como argumento para não aplicar o crime no direito interno não possuem caráter vinculante. Mas, se há recomendações internacionais expressas para que o crime não seja aplicado, mesmo não havendo caráter vinculante, porque os juízes deveriam continuar o aplicando?

\footnotetext{
${ }^{18} \mathrm{NUCCl}$, Guilherme de Souza. Código Penal Comentado. Editora Forense. 17 $7^{\text {a }}$ Edição. p. 1486.

19 O que o autor reivindica é que seja aplicado o princípio da legalidade em todas as suas vertentes, garantindo um julgamento justo e imparcial.

${ }^{20}$ BRASIL, Superior Tribunal de Justiça. RESP № 1.640.084 - SP (2016/0032106-0). Disponível em: $<$ https://ww2.stj.jus.br/processo/revista/documento/mediado/?componente=ITA\&sequencial=1564541 \&num_registro=201600321060\&data=20170201\&formato=PDF>. Acesso em: out, 2017.
} 


\title{
4 ANÁLISE DOS JULGADOS SOBRE O CRIME DE DESACATO NOS PAÍSES DA AMÉRICA LATINA
}

É fato que a sociedade interamericana está rumando no sentido da abolitio criminis do crime de desacato, como prevê os relatórios pela Comissão Internacional de Direitos Humanos, que ocorre de dois em dois anos. Segundo trabalho publicado pelo Artigo 19:

\begin{abstract}
A ideia de criminalizar a ofensa contra agentes públicos não é exclusividade do Brasil. Entretanto, observa-se uma tendência de descriminalização do desacato à autoridade em países que costumavam tipificar esta conduta.

Um levantamento da Relatoria Especial para a Liberdade de Expressão da Comissão Interamericana de Direitos Humanos, lançado em 2013, compilou alguns dos países que revogaram o crime de desacato, seja por meio de mudanças legislativas ou por decisões de tribunais superiores: Argentina em 1993, Paraguai em 1998, Costa Rica em 2002, Chile, Honduras e Panamá em 2005, Guatemala em 2006, Nicarágua em 2007 e Bolívia em 2012.21
\end{abstract}

Apesar da avaliação positiva averiguada nos últimos anos, o Brasil segue sem obedecer aos Tratados Internacionais que ratificou. Segundo o Artigo "Abolitio Criminis do Desacato":

\begin{abstract}
Esse relevo dispensado ao fim das leis de desacato na américa latina se justifica, em parte, pela violação à liberdade de expressão, garantia muito enfatizada no continente. Isso pois, tal garantia possui lugar de destaque no debate acerca dos direitos humanos na região devido ao histórico comum de ditaduras e supressão da liberdade de expressão. ${ }^{22}$
\end{abstract}

Assim, alguns países tiveram casos importantes que justificaram os primeiros posicionamentos das Comissões Internacionais, como é o caso da Argentina:

${ }^{21}$ MARQUES, MARTINS, RIELLI. Teses jurídicas para a descriminalização do desacato. Artigo 19. 2017. Disponível em: <http://artigo19.org/blog/2017/04/11/defesa-da-liberdade-de-expressao-tesesjuridicas-para-a-descriminalizacao-do-desacato/ > Acesso em 20 mar. 2018.p.8.

${ }_{22}$ VAZ OLIVEIRA, SOARES DE OLIVEIRA. Abolitio criminis do desacato: um olhar sobre a relação entre autoridade pública e o particular na américa latina. Revista do CAAP. jul./dez.2010. Disponível em:<file:///C:/Users/HP\%20063BR/Desktop/ABOLITIO\%20CRIMINIS\%20DO\%20DESACATO\%20AR TIGO.pdf.> Acesso em: 20 mar. 2018. p. 23. 


\title{
4.1- ARGENTINA
}

A Argentina teve uma importância crucial para a manifestação da Comissão Internacional de Direitos Humanos sobre o delito de desacato. É que no caso Horácio Verbistiky vs. Argentina, como se analisará, o réu foi condenado por todas as instâncias internas, inclusive pela Corte Suprema de Justiça de La Nación, sendo absolvido somente pela Comissão IDH. Por conta disto, foi firmado um acordo: o governo argentino se comprometeu de derrogar o crime de desacato, e as partes solicitaram à Comissão IDH que se manifestasse sobre o delito.

De acordo com o Artigo Abolitio Criminis do crime de desacato:

Em 6 de março de 1988 o jornalista Horácio Verbistiky publicou no periódico argentino Pagina 12 uma matéria com o nome Cicatrices de dos Guerras. Em seu texto, o jornalista se referiu ao Ministro Augusto Belluscio, da Corte Suprema Argentina, como "asqueroso". Diante da situação, o Ministro Belluscio iniciou uma ação civil de injúria contra o jornalista. Invocando o princípio lura Novit Curia, a juíza de primeira instância decidiu converter a ação privada em ação pública de desacato e condenou o jornalista, atribuindo-lhe a intenção de difamar o ministro. Após recurso, em julho de 1991, a câmara de apelações confirmou a sentença.

\begin{abstract}
Em fevereiro de 1992, o recurso extraordinário, assim como o primeiro recurso, foi declarado improcedente. Então, o caso foi submetido à Comissão IDH, que iniciou o procedimento ainda em 1992. No mesmo ano, no mês de setembro, as partes convencionaram uma solução amistosa para o episódio. Dentre os pontos de maior repercussão do acordo destacam-se dois: o primeiro foi o compromisso assumido pelo governo argentino de derrogar o artigo 244 do Código Penal (desacato); já o segundo foi a solicitação feita pelas partes à Comissão IDH para que esta se posicionasse acerca da compatibilidade entre a figura penal do desacato com as normas do Pacto de São José da Costa Rica (Convenção Americana de Direitos Humanos CADH). Cumprindo o compromisso assumido, em 3 de junho de 1993, através da lei nacional $n$. 24.198, houve a abolitio criminis do tipo penal desacato na Argentina. Por sua vez, no informe anual de 1994, publicado em 1995, a Comissão IDH emitiu o parecer solicitado no acordo do caso. ${ }^{23}$
\end{abstract}

23 VAZ OLIVEIRA, SOARES DE OLIVEIRA. Abolitio criminis do desacato: um olhar sobre a relação entre autoridade pública e o particular na américa latina. Revista do CAAP. jul./dez.2010. Disponível em:<file://C:/Users/HP\%20063BR/Desktop/ABOLITIO\%20CRIMINIS\%20DO\%20DESACATO\%20AR TIGO.pdf.> Acesso em: 20 mar. 2018. p. 23. 
É nessa oportunidade que, segundo a fonte do Artigo 19, já mencionado neste capítulo, há a primeira manifestação da Comissão sobre esse delito, através do Informe sobre a Compatibilidade entre as leis de desacato e a Convenção Americana de Direitos Humanos, em 1995:

Em 1995, a Comissão Interamericana de Direitos Humanos publicou o seu primeiro relatório analisando o crime de desacato, denominado "Informe sobre a compatibilidade entre as leis de desacato e a Convenção Americana de Direitos Humanos", e após analisar os contextos locais e os impactos desses crimes para a liberdade de expressão, a Comissão chegou a seis conclusões principais:

1) As leis de desacato se prestam ao abuso como um meio para silenciar idéias e opiniões impopulares, reprimindo o debate crítico, o qual é essencial para o efetivo funcionamento das instituições democráticas;

2) As leis de desacato proporcionam um maior nível de proteção aos funcionários públicos do que aos cidadãos comuns. A Comissão ressalta que em uma sociedade democrática, as pessoas públicas devem estar mais expostas - e não menos expostas - às criticas e ao escrutínio público;

3) As leis de desacato impedem o controle popular para impedir abusos dos poderes coercitivos exercidos pelos agentes públicos;

4) As leis de desacato restringem indevidamente a livre expressão porque não contemplam o fato de que muitas críticas se baseiam em opiniões;

5) As leis de desacato provocam a auto-censura. As leis de desacato, além de limitar de forma direta a liberdade de expressão, também restingem indiretamente esse direito porque trazem consigo a ameaça de detenção para a coletividade como um todo;

6) Diante desses pontos, a Comissão concluiu que as leis de desacato não são compatíveis com a Convenção Americana de Direitos Humanos e que os países membros deveriam revogar ou reformar sua legislação sobre o tema. ${ }^{24}$

Dessa forma, o caso Argentino fez com que a Comissão identificasse que a legitimidade dos fins e a proporcionalidade da repressão criminal é que são os problemas enfrentados pela existência do delito.

\subsection{CHILE}

O Chile retirou o crime de desacato de seu ordenamento jurídico em 2001, antes previsto na Lei de Segurança do Estado, número 19.733.

O caso mais famoso envolvendo o delito é o Palamara Iribarne Vs. Chile, conforme relata a CIDH:

${ }^{24}$ MARQUES, MARTINS, RIELLI. Op. Cit. p.27-28, 
Em 16 de janeiro 1996 a Comissão Interamericana de Direitos Humanos (doravante denominada "Comissão Interamericana" ou "a CIDH") recebeu uma denúncia apresentada por Humberto Palamara Iribarne, representado pelo Centro pela Justiça e o Direito Internacional (CEJIL) e Human Rights Watch/Américas (doravante denominados conjuntamente "os peticionários"), na qual alega a responsabilidade internacional da República de Chile (doravante denominado "o Estado") por proibir a publicação do livro "Ética eServiços de Inteligência" do Sr. Palamara Iribarne, e por condená-lo por desacato num julgamento que não contou com respeito às garantias do devido processo legal.

A denúncia indica que o Sr. Palamara Iribarne escreveu e tentou publicar um livro titulado "Ética e Serviços de Inteligência", no qual abordava aspectos relacionados com a inteligência militar e a necessidade de adequá-la a certos parâmetros éticos. O Sr. Palamara Iribarne, oficial aposentado da Armada chilena, desempenhava na época dos fatos como funcionário civil contratado a honorários pela Marinha de Chile na cidade de Punta Arenas. Os peticionários alegam que o texto citado não era considerado um artigo de imprensa e que tampouco continha informação confidencial. Apesar disso, o Sr. Palamara Iribarne entregou quatro cópias do livro no mês de fevereiro de 1993 ao Comandante-Chefe da Terceira Zona Naval de Chile.

Em $1^{\circ}$ de março de 1993 o mencionado comandante naval notificou por telefone ao Sr. Palamara Iribarne que a publicação de seu livro havia sido proibida pela instituição por estimar que seu conteúdo atentava contra a segurança e defesa nacional, e que em consequência, todos os exemplares existentes deveriam ser recolhidos.

Os peticionários relatam que as autoridades navais ordenaram ao autor do livro que se abstivera de fazer comentários "críticos públicos ou privados, escritos ou falados, que pudessem menosprezar ou danificar a imagem da Instituição, autoridade naval ou de pessoa encarregada da ação judicial e investigação sumária administrativa contra sua pessoa". A Marinha chilena levou a cabo duas perícias a fim de determinar se o conteúdo do livro atentava contra a segurança nacional; e o resultado em ambos casos foi que não se havia vulnerado a reserva de segurança da instituição militar.

Humberto Palamara Iribarne convocou uma conferência de imprensa em sua residência, durante a qual criticou a atuação da Promotoria Naval no processo contra sua pessoa. A ação penal por desacato concluiu pela condenação do réu e foi confirmada pela Corte Suprema de Chile.

O Estado chileno argumenta que, quanto ao fundo da denúncia, não houve violação do direito à liberdade de expressão em prejuízo do Sr. Palamara Iribarne. Alega que o direito de liberdade de expressão encontrase limitado pelo respeito ao direito à reputação dos demais, razão pela qual defende que o Sr. Palamara Iribarne violou o direito que tem as pessoas ao respeito a sua honra e ao reconhecimento de sua dignidade.

Em suma, o Estado sustenta que não houve violação alguma dos direitos humanos do Sr. Palamara Iribarne e que, de todas maneiras, os recursos da jurisdição interna não foram esgotados. Por conseguinte, solicita que a Comissão Interamericana recuse a petição.

Na sentença de 3 de janeiro de 1995, resolveu revogar a decisão de primeira instância e condenar o Sr. Palmara por desacato. A pena consistiu em 61 dias de "prisão menor em grau mínimo, multa de 11 salários e suspensão do cargo ou ofício público durante o tempo da condenação". 
A defesa do Sr. Palamara Iribarne apresentou em 9 de janeiro de 1995 a Corte Suprema de Chile um recurso de queixa contra os ministros da Corte Marcial que o condenaram. A Corte Suprema indeferiu o recurso de queixa em 20 de julho de 1995, com o qual transitou em julgado a condenação determinada pela Corte Marcial de Valparaíso. ${ }^{25}$

Por fim, segundo este mesmo documento, a Comissão decidiu que realmente houve violação de direitos protegidos nos artigos 8, 13 e 21 da Convenção Americana, sendo finalmente absolvido em 2005:

Também em relação a desproporcionalidade apontada, a Corte Interamericana de Direitos Humanos expressou, no já citado caso Palamara Iribarne v. Chile : "A Corte considera que a legislação sobre desacato aplicada ao senhor Palamara Iribarne estabelecia sanções desproporcionais pela manifestação de críticas sobre o funcionamento das instituições estatais e seus membros, suprimindo o debate essencial para o funcionamento de um sistema verdadeiramente democrático e restringindo desnecessariamente 0 direito à liberdade de pensamento e expressão. ${ }^{26}$

No Informe anual del relator especial para la libertad de expresión do ano de 2000, houve atenção à outro caso no Chile envolvendo o crime de desacato:

Outro caso é o de Alejandra Matus, que abandonou o Chile em 1999 para evitar a prisão por publicação do livro "O livro negro da justiça chilena". O livro critica o poder judicial chileno por falta de independência e a corrupção dos juzes durante o regime do general Augusto Pinochet. A acusação contra Matus se baseia no Artigo 6 (b) da Lei de Segurança do Estado, e foi apresentada pelo juiz da Corte Suprema, Servando Jordán por as acusações dirigidas contra ele. (tradução nossa) ${ }^{27}$

Segundo o Emol, jornal chileno, com a nova "Ley de Prensa", de 2001, Matus pode retornar ao Chile. ${ }^{28}$

\footnotetext{
25 Corte interamericana de Direitos Humanos. Disponível em: http://cidh.oas.org/annualrep/2001port/chi11571.htm. Acesso em: 20 mar. 2018

26 Corte interamericana de Direitos Humanos. Disponível em: http://cidh.oas.org/annualrep/2001port/chi11571.htm. Acesso em: 20 mar. 2018

27 Informe anual del relator especial para la libertad de expresión. Organização dos Estados Americanos. 2000.2 Disponível em: http://www.oas.org/es/cidh/expresion/docs/informes/anuales/Informe\%20Anual\%202000.pdf. Acesso em: 20 mar. 2018
}

28 Levantan prohibición de circular al "Libro negro de la Justicia chilena". Emol. Santiago. 2001. Disponível em: http://www.emol.com/noticias/nacional/2001/10/19/68997/levantan-prohibicion-decircular-al-libro-negro-de-la-justicia-chilena.html. Acesso em: 20 mar. 2018 


\title{
4.3 COSTA RICA
}

\author{
Em 2003, houve decisão da Corte Internacional de Direitos Humanos, \\ considerando a Costa Rica culpada pela condenação do jornalista Herrera Ulloa.
}

Segundo o artigo "Abolitio Criminis do crime de desacato":

Em 1995, o Jornalista Mauricio Herrera Ulloa publicou alguns artigos no jornal Lá Nación reproduzindo parcialmente informações contrárias a um diplomata costarriquenho que haviam sido divulgadas, inicialmente, pela mídia européia. A matéria veiculava supostos questionamentos feitos à Felix Przedboski Chawa, cônsul ad honorem de Costa Rica na Organização Internacional de Energia Atômica na Áustria. O jornalista foi processado e condenado penal e civilmente, esta última em caráter solidário com o jornal.

Além disso, o La Nación teve que publicar a parte dispositiva da sentença no jornal e ligar todas as pesquisas feitas em seu site, com o nome 'Przedboski', à parte dispositiva da sentença. Em 2003, o caso foi enviado para apreciação da Corte IDH. Consoante ao entendimento apresentado nos relatórios elaborados pela Comissão IDH36, os juízes se posicionaram no sentido de afirmar a importância da liberdade de expressão para a democracia, alertando acerca da necessidade de maior exposição das figuras públicas às críticas. Em decorrência, Costa Rica foi considerada culpada e foi coagida a tornar sem efeitos a condenação do jornalista. ${ }^{29}$

A Corte ainda estabeleceu que o Estado da Costa Rica compatibilize seu ordenamento jurídico interno com a Convenção Americana sobre Direitos Humanos.

\subsection{PARAGUAI}

O caso emblemático envolvendo o Paraguai foi durante a disputa eleitoral em 1992, Ricardo Canesse Vs. Paraguay:

Segundo o artigo "Abolitio Criminis do crime de desacato:

Os fatos se deram no contexto do pleito paraguaio de 1992. Durante a campanha política, o candidato à presidência Ricardo Canese fez declarações nas quais questionou a idoneidade e integridade de seu rival, Juan Carlos Wasmosy. Nas alegações, Canese levantou possíveis irregularidades na construção do complexo hidroelétrico binacional de Itaipú e uma suposta relação de seu adversário com a família do ex ditador Alfredo Stroessner. A construção da central elétrica esteve, parcialmente, a cargo da empresa CONEMPA (Consorcio de Empresas Constructoras Paraguayas), da qual Juan Carlos Wasmosy havia sido presidente. Os diretores da CONEMPA moveram ação contra Canese por difamação e injúria. Ao final do processo, em maio de 2001, Canesse foi condenado a dois meses de prisão,

29 VAZ OLIVEIRA, SOARES DE OLIVEIRA. Op Cit. p. 26 
ao pagamento de indenização por danos morais e custas processuais. Além da pena, durante o transcorrer do processo, foi negado à Canesse, por diversas vezes, a possibilidade de fazer viagens para fora do país. Em junho de 2002 o caso foi apresentado à Corte IDH. Paralelamente, os advogados do réu entraram com recurso contra a condenação criminal na Corte Suprema de Justiça do Paraguai, que foi conhecido em dezembro, absolvendo Canesse. A Corte IDH, em sua decisão, afirmou que não somente a sentença penal havia sido uma sanção desnecessária e excessiva, mas também o trâmite processual, durante o qual Ricardo Canesse não pode sair do país por diversas vezes. Outrossim, os juízes reiteraram a importância do debate aberto e da liberdade de expressão, sobremodo quando se tratar de questões envolvendo assuntos de interesse público. ${ }^{30}$

Pode-se perceber que diante de uma disputa política democrática é imprescindível que haja espaço para a manifestação de possíveis irregularidades realizadas pelo candidato opositor. Sendo assim, é dada a importância da referida decisão proferida pela Corte IDH.

\title{
4.5 PERU
}

Segundo a Organização dos Estados Americanos, no Peru existe um projeto de reforma do Código Penal em relação aos crimes contra a honra, bem como projetos de lei que visam derrubar o crime de desacato:

\begin{abstract}
Igualmente, a Relatoria recebeu informação que neste país existe em andamento no Congresso um projeto de reforma ao Código Penal referente aos delitos contra a honra. A Relatoria insta o Estado a avançar nas modificações necessárias, de acordo com as considerações expostas no presente relatório. Por último, a Relatoria recebeu informação de que também no Peru existem vários projetos de lei para derrogar o delito de desacato, apresentados à Comissão de Justiça do Congresso. Igualmente, existiria também um projeto de lei que descriminaliza a injúria e a difamação, caso se trate de informação falsa ou opiniões através da imprensa contra um funcionário, guardando determinadas circunstâncias. ${ }^{31}$
\end{abstract}

Dessa forma, observa-se que a descriminalização do crime se dará, possivelmente, pelo legislativo.

\subsection{BOLÍVIA}

30 Ibidem. p. 26

${ }^{31}$ Capítulo V - leis de desacato e difamação criminal. Organização dos Estados Americanos. Disponível em: http://www.oas.org/es/cidh/expresion/showarticle.asp?artID=533\&lID=4. Acesso em: 20 mar. 2018. 
Segundo o Artigo 19, a Bolívia teria retirado do seu ordenamento jurídico o crime de desacato em 2012:

Nos casos da Guatemala e da Bolívia, inclusive, as decisões judiciais que revogaram o desacato reconheceram expressamente a influência da Corte e da Comissão Interamericana, argumentando que a permanência do crime no ordenamento jurídico representava uma medida desproporcional e lesiva à liberdade de expressão. O Tribunal Constitucional Boliviano reconheceu a"tendência regional de supressão do delito mencionado, a qual também se encontra respaldada por organismos de direitos humanos (...)". Outro argumento bastante utilizado nestas decisões diz respeito ao maior nível de tolerância a críticas que deve ser exigido dos agentes públicos no exercício de suas funções. ${ }^{32}$

Diferentemente do que ocorre no Peru, a Bolívia escolhe o caminho do judiciário.

\section{CONCLUSÃO}

É notória a posição da jurisprudência internacional no sentido de revogar as disposições que preveem o crime de desacato.

Assim, de acordo com o artigo 19:

Dessa forma, primeiro, qualquer restrição à liberdade de expressão deverá estar prevista por lei ou regulamento de forma clara e objetiva. Isto é, a previsão não admite que uma lei demasiadamente ampla e não facilmente acessível disponha sobre qualquer restrição à liberdade de expressão, pois estes tipos de leis vagas permitem interpretações muito vastas, possibilitando abusos aos padrões internacionais. Além disso, sabe-se que tais leis imprecisas causam um efeito inibidor decorrente da insegurança jurídica, pois os indivíduos, ao não saberem quais manifestações poderão ser definidas como violação a outros direitos, acabam, por cautela, se autocensurando em assuntos legítimos. A segunda parte do teste determina que a restrição deverá proteger um fim considerado legítimo perante o direito internacional.

O próprio parágrafo 19 em suas alíneas "a" e "b" define quais são estes propósitos e trata-se de consenso internacional que tais fins representam uma lista taxativa, assim sendo, nenhuma outra finalidade poderá ser agregada a lista. ${ }^{33}$

32 MARQUES, MARTINS, RIELLI. Op Cit. p. 14.

${ }^{33}$ MARQUES, MARTINS, RIELLI. Op Cit. p. 40-41 
Como se analisou, o desacato reflete em arbitrariedade porque é difícil a sua constatação e determinação: a mesma frase proferida para diferentes agentes estatais pode ofender um e não o outro. Dessa forma, nunca se sabe se o que será dito ofenderá ou não, inclusive quando se faz uma crítica institucional ao Estado, gerando por tanto, a autocensura.

No último informe anual da Comissão Interamericana de 2016, o Brasil foi citado por mais de 20 vezes a respeito de aplicações arbitrárias em relação ao crime.

Dessa forma, sabendo que o Ministério Público Federal afirmou seu posicionamento a favor da descriminalização do desacato ${ }^{34}$, e que essa descriminalização possui também apoio legislativo dos projetos de Lei 236/201227 (que institui o novo código penal) e o projeto de Lei 602/201528 (que revoga o crime de desacato), além das decisões isoladas de juízes que relutam em aplicar um crime claramente inconvencional e inconstitucional, passamos a acreditar que em breve teremos a mesma sorte dos demais países da América Latina.

Ainda, conforme o exposto pelo artigo Abolitio Criminis do Desacato, até então, nos países da América Latina se observou que os Estados, seja pela via legislativa ou executiva, retiraram o crime de desacato do ordenamento porque houve algum um caso emblemático envolvendo alguma personalidade pública:

Como se viu nos relatórios da Comissão IDH e na jurisprudência da Corte $\mathrm{IDH}$, os primeiros passos para se abolir o crime de desacato nos países da América Latina têm se dado, em grande parte, por ocasião de casos emblemáticos, envolvendo grandes personalidades. ${ }^{35}$

É muito provável que haja razão neste argumento, se formos comparar com outros casos no Brasil, como por exemplo, a alteração da Lei dos Crimes Hediondos ocorrida em 1994.

O crime de homicídio qualificado não era arrolado na lei, mas por conta da pressão social causada pelo caso do homicídio de Daniella Perez e do caso da chacina da Igreja da Candelária, houve a mudança da lei, incluindo o homicídio qualificado como crime hediondo. ${ }^{36}$

Por fim, apesar de a última decisão do STJ ter sido a favor da continuidade do crime de desacato no ordenamento, nos resta esperar a manifestação do Supremo Tribunal Federal.

\footnotetext{
${ }^{34}$ Segundo o supracitado artigo 19, O Ministério Público Federal, que já havia se manifestado neste caso, por meio da Procuradoria Federal dos Direitos (PFDC) do Cidadão, reafirmou seu posicionamento a favor da descriminalização do desacato por meio de uma Representação encaminhada em junho de 2016 à Procuradoria-Geral da República.Neste documento, a PFDC requereu que a Procuradoria-Geral entrasse com uma ação de inconstitucionalidade em relação ao crime de desacato, além de fornecer uma série de argumentos, dentre eles a não-convencionalidade, para subsidiar esta ação. Disponível em: http://pfdc.pgr.mpf.mp.br/atuacao-e-conteudos-deapoio/temas. Acesso em: 25 mar. 2018.
}

35 VAZ OLIVEIRA, SOARES DE OLIVEIRA. Op Cit. p. 30

${ }^{36}$ Disponível em: http://justificando.cartacapital.com.br/2015/07/24/os-25-anos-de-uma-lei-hedionda/.

Carta Capital. 03 abril 2018. Acesso em 03 abril 2018. 


\section{REFERÊNCIAS}

BITENCOURT, César Roberto. 2017.

BITENCOURT, César Roberto. Código penal comentado. Saraiva, 2015. 9ำ Edição.

BOTH, Laura Garbini; GONÇALVES, Ane Elise Brandalise. O crime de desacato e sua correlação com a atitude repressiva estatal. Revista Quaestio luris, Rio de Janeiro, n. 1, v. 10., set. 2016.

BRASIL, Superior Tribunal de Justiça. RESP № 1.640 .084 - SP (2016/0032106-0). Disponível em: <http://www.stj.jus.br/static_files/STJ/Midias/arquivos/Noticias/RECURSO\%20ESPE CIAL\%20N\%C2\%BA\%201640084.pdf>. Acesso em: out, 2017.

BRASIL. Código Criminal do Império do Brasil. Disponível em: <http://www.planalto.gov.br/ccivil_03/leis/lim/LIM-16-12-1830.htm>.Acesso em: set 2017

BRASIL. Código Penal Brasileiro. Disponível em: <http://www.planalto.gov.br/ccivil_03/decreto-lei/Del2848compilado.htm>.Acesso em: set 2017.

BRASIL. Código Penal de 1890. Disponível em: $<$ http://www2.camara.leg.br/legin/fed/decret/1824-1899/decreto-847-11-outubro1890-503086-publicacaooriginal-1-pe.html>. Acesso em: set 2017.

CAPEZ, Fernando; Prado, Stela. Código penal comentado. Saraiva, 2016. $7^{0}$ Edição.

Capítulo V - leis de desacato e difamação criminal. Organização dos Estados Americanos. Disponível em: http://www.oas.org/es/cidh/expresion/showarticle.asp?artID=533\&IID=4. Acesso em: 20 mar. 2018.

Corte interamericana de Direitos Humanos. Disponível em: http://cidh.oas.org/annualrep/2001port/chi11571.htm. Acesso em: 20 mar. 2018

COSTA, Álvaro Mayrink Da. Direito penal: Parte especial injustos contra a administração pública. Volume 7. Cidade: Forense, 2011. 6ํㅡㄹição.

Disponível em: http://justificando.cartacapital.com.br/2015/07/24/os-25-anos-de-umalei-hedionda/. Carta Capital. 03 abril 2018. Acesso em 03 abril 2018.

EMPÓRIO DO DIREITO. Desacato não é crime, diz Juiz em controle de convencionalidade. Disponível em: <http://emporiododireito.com.br/backup/desacatonao-e-crime-diz-juiz-em-controle-de-convencionalidade/>. Acesso em: out, 2017. 
Informe anual del relator especial para la libertad de expresión. Organização dos Estados Americanos. 2000.2 Disponível http://www.oas.org/es/cidh/expresion/docs/informes/anuales/Informe\%20Anual\%202 000.pdf. Acesso em: 20 mar. 2018

Levantan prohibición de circular al "Libro negro de la Justicia chilena". Emol. Santiago. $2001 . \quad$ Disponível em: http://www.emol.com/noticias/nacional/2001/10/19/68997/levantan-prohibicion-decircular-al-libro-negro-de-la-justicia-chilena.html. Acesso em: 20 mar. 2018

MARQUES, MARTINS, RIELLI. Teses jurídicas para a descriminalização do desacato. Artigo 19. 2017. Disponível em: <http://artigo19.org/blog/2017/04/11/defesa-daliberdade-de-expressao-teses-juridicas-para-a-descriminalizacao-do-desacato/ > Acesso em 20 mar. 2018.

$\mathrm{NUCCl}$, Guilherme de Souza. Código Penal Comentado. Editora Forense. 17 Edição.

Ordenações Filipinas: Ordenações e leis do Reino de Portugal Recopiladas por mandato d'el Rei Filipi, o Primeiro. Disponível em: <http://www1.ci.uc.pt/ihti/proj/filipinas/15p1200.htm>. Acesso em: set 2017.

PRADO, Luiz Regis. Curso de direito penal brasileiro. Volume 4. São Paulo: Revista dos Tribunais, 2002. p. 506-507.

SILVA, Rogerio Luiz Nery da; MASSON, Daiane Garcia. O DIREITO FUNDAMENTAL SOCIAL À EDUCAÇÃO COMO MANIFESTAÇÃO DA IGUALDADE E DA LIBERDADE, NO CONTEXTO DA POLÍTICA PÚBLICA PLANO DE DESENVOLVIMENTO DA EDUCAÇÃO (PDE). Revista Juridica, [S.I.], v. 4, n. 41, p. 363 - 383, jan. 2016. ISSN 2316-753X. Disponível em: <http://revista.unicuritiba.edu.br/index.php/RevJur/article/view/1465/998>. Acesso em: 18 abr. 2020. doi:http://dx.doi.org/10.21902/revistajur.2316-753X.v4i41.1465.

VAZ OLIVEIRA, SOARES DE OLIVEIRA. Abolitio criminis do desacato: um olhar sobre a relação entre autoridade pública e o particular na américa latina. Revista do CAAP. jul./dez.2010.

Disponível em:<file://C:/Users/HP\%20063BR/Desktop/ABOLITIO\%20CRIMINIS\%20DO\%20DE SACATO\%20ARTIGO.pdf.> Acesso em: 20 mar. 2018.

ZAFFARONI, Eugenio Raúl. Em busca das penas perdidas. Rio de Janeiro: Revan, 1991. 